\title{
Stratigraphy of late Palaeocene events in the Middle East: implications for low- to middle-latitude successions and correlations
}

\author{
ROBERT P. SPEIJER ${ }^{1}$, BIRGER SCHMITZ ${ }^{2}$ \& PETER LUGER ${ }^{1,3}$ \\ ${ }^{1}$ Department of Geosciences, Bremen University, PO Box 330440, 28334 Bremen, Germany \\ (e-mail:speijer@uni-bremen.de) \\ ${ }^{2}$ Department of Marine Geology, Earth Sciences Centre, Göteborg University, PO Box 460, 40530 Göteborg, Sweden \\ ${ }^{3}$ Present address: Institute of Applied Geosciences II, Technical University Berlin, Ernst Reuter Platz 1, EB10, \\ 10587 Berlin, Germany
}

\begin{abstract}
We have investigated the upper Palaeocene stratigraphical record in four sections in Egypt and one in Israel. The sections are arranged on a depth transect across the southern Tethyan margin. In all sections, a $\delta^{13} \mathrm{C}$ excursion and benthic foraminiferal extinctions coincide at a level within planktic foraminiferal Zone P5. In three sections, a bed (sapropelic in two of the deeper profiles) contains extraordinarily transient benthic and planktic foraminifera assemblages. These planktic assemblages are dominated by Acarinina and contain rare to common Morozovella allisonensis and Globanomalina luxorensis, but unusually few other Morozovella. The extremely restricted stratigraphical range of $M$. allisonensis to the lower part of the $\delta^{13} \mathrm{C}$ excursion enables: (1) a three-fold subdivision of Zone P5, (2) accurate correlation to the best sections spanning the $\delta^{13} \mathrm{C}$ excursion in the Atlantic and Pacific and (3) assessment of stratigraphical completeness over the $\delta^{13} \mathrm{C}$ excursion in other (sub)tropical successions. Discontinuities and especially dissolution intervals in many low- to middle-latitude marine successions elsewhere, as in two Middle East sections, preclude an accurate correlation within the lower part of the $\delta^{13} \mathrm{C}$ excursion ( $=M$. allisonensis Zone P5b). Three studied sections can provide the best coverage of the sequence of events over the onset and early part of the $\delta^{13} \mathrm{C}$ excursion in the Middle East, but as in most known sections, probably none constitutes a complete upper Palaeocene-lower Eocene record.
\end{abstract}

Keywords: Middle East, upper Paleocene, global events, stratigraphy.

Marine and terrestrial deposits from numerous localities world-wide indicate that global biotic, oceanic and climatic changes occurred in a geologically short time interval near the end of the Palaeocene Epoch. High-latitude warming is thought to have resulted in a dominance of deep water formation in the low latitudes, leading to a major extinction event in deep-sea benthic foraminifera (Kennett \& Stott 1991; Thomas \& Shackleton 1996). Simultaneously, marginal shelf seas experienced similar although less severe biotic changes (e.g. Speijer et al. 1995), and on land, an important mammal turnover took place (e.g. Gingerich 1980). These biotic changes associated with the so-called late Palaeocene thermal maximum (Zachos et al. 1993) coincide with a sharp negative carbon-isotopic excursion in marine and terrestrial carbonates (e.g. Stott et al. 1996). Kennett \& Stott (1991) proposed rapid onset $(<3 \mathrm{ka})$ of the $\delta^{13} \mathrm{C}$ excursion and a total duration of c. $100 \mathrm{ka}$ for the return to stable values. A useful temporal framework can, however, only be based on a firm integrated stratigraphy and full evaluation of the completeness of the stratigraphical record (Aubry 1998). Most, if not all, upper Palaeocene to lower Eocene successions are riddled with discontinuities (often paraconformities), both in shelf and deep-sea successions (Aubry et al. 1996). These discontinuities are not easily detected and therefore temporal estimates for latest Palaeocene events should be treated with great caution (Aubry 1998). Rigorous integration of stratigraphical data is required to determine the sequence and temporal relationships of latest Palaeocene events. On the basis of our collective upper Palaeocene stratigraphical data from Egypt and Israel, we attempt to reconstruct the sequence of events connected to the $\delta^{13} \mathrm{C}$ excursion and select criteria for regional and global (low- to middle-latitude) correlations. We synthesize these stratigraphical data in part from our previous studies, which focused more on biotic and palaeoenvironmental change (e.g. Speijer 1994; Charisi \& Schmitz 1995; Speijer et al. 1995, 1996; Schmitz et al. 1996, 1997b), and add new data from highresolution records across the $\delta^{13} \mathrm{C}$ excursion. Calcareous nannoplankton data on some of these sections in our earlier papers were generated by various workers, which may have led to taxonomical inconsistencies (see below). In order to prevent miscorrelation, we refrain from integrating these calcareous nannoplankton data here and so we focus on $\delta^{13} \mathrm{C}$ and benthic and planktic foraminifera records.

\section{Marine stratigraphical markers related to the late Palaeocene thermal maximum}

Since a great variety of environmental settings experienced changes in biotic and abiotic development during the late Palaeocene thermal maximum, these changes provide ample opportunities for regional and global correlation. The following parameters are now (relatively) well established in the marine realm.

The global, marine and terrestrial distribution of the $\delta^{13} \mathrm{C}$ excursion and its coincidence with marked biotic changes suggests that the onset of the $\delta^{13} \mathrm{C}$ excursion was a geologically synchronous and almost instantaneous event (e.g. Pak \& Miller 1992; Thomas \& Shackleton 1996) and it provides an excellent tool for land-sea correlations (e.g. Koch et al. 1992; Stott et al. 1996). 
In bathyal to abyssal realms, the cosmopolitan Gavelinella beccariiformis assemblage suddenly became extinct, being replaced (long-term) in many basins by the Nuttallides truempyi assemblage (Tjalsma \& Lohmann 1983; Thomas 1998). Thus, in deep-sea deposits (above the CCD), the benthic extinction event marks a well pronounced taxonomical turnover that enables global biostratigraphical correlation (e.g. Berggren \& Miller 1989).

The benthic extinction event and the $\delta^{13} \mathrm{C}$ excursion are situated within the middle part of planktic foraminifera Zone P5 (Morozovella velascoensis Zone; Berggren et al. 1995). In the equatorial Pacific (ODP Hole 865C), the sudden appearance of Morozovella allisonensis and two other species coincides with the $\delta^{13} \mathrm{C}$ excursion and the benthic extinction event and thus these could serve as excellent marker species (Kelly et al. 1996, 1998). In the Mediterranean region (and possibly in Pakistan and New Zealand), the $\delta^{13} \mathrm{C}$ excursion and the extinction event coincide with the lowest common occurrence of Globanomalina luxorensis, the direct precursor of Pseudohastigerina wilcoxensis (Speijer \& Samir 1997). In Spain, the highest occurrence of Igorina laevigata coincides with the onset of the $\delta^{13} \mathrm{C}$ excursion and the benthic extinction event (Arenillas \& Molina 1996).

Many calcareous-nannofossil taxa appear or disappear within or close to the interval of the benthic extinction event and $\delta^{13} \mathrm{C}$ excursion, enabling high-resolution correlations. There remains, however, considerable disagreement between experts on taxonomical concepts of the marker species within the Rhomboaster-Tribrachiatus lineage (e.g. Monechi \& Angori 1998 and references therein). Consequently, the benthic extinction event and the $\delta^{13} \mathrm{C}$ excursion are variously placed within zones NP9 or NP10. This problem is further enhanced by widespread occurrence of stratigraphical gaps close to the NP9/NP10 zonal boundary (Aubry et al. 1996).

Several upper Palaeocene successions, particularly those in middle to high latitudes are marked by a sharp increase in kaolinite close to the $\delta^{13} \mathrm{C}$ excursion. This is interpreted as a latitudinal expansion of warm and humid conditions during the latest Palaeocene (e.g. Gibson et al. 1993; Robert \& Kennett 1994). For stratigraphical purposes, the kaolinite peak can at least be used to approximate the interval of interest.

\section{Geological setting}

In southern Israel and eastern Egypt, the upper Palaeocene to lower Eocene is mostly represented by marls and shales, deposited in an epicontinental basin on the north-western margin of the Arabian-Nubian shield (Bartov \& Steinitz 1977; Said 1990a). This basin had its maximum southward extension into present-day Sudan during the late Palaeocene (Barazi \& Kuss 1987). The shoreline east of Egypt and Israel probably trended in a SW-NE direction and bathymetrical estimates indicate that the basin generally deepened in a NNW direction (Fig. 1; Speijer \& Van der Zwaan 1994). Local swells, ramps, and islands, particularly north of central Sinai (the Sinai-Negev fold-belt) interrupt this general deepening trend (Moustafa \& Khalil 1990; Said 1990a). The high abundance of pelagic microfossils in all sections indicate open connections to the Tethys. Apart from block faulting and tilting related to the opening of the Red Sea, Paleogene successions in the Middle East experienced very little deformation after deposition (Said 1990b).

We studied five sections arranged on a neritic to bathyal transect across the southern Tethyan margin (Fig. 1). The Ben

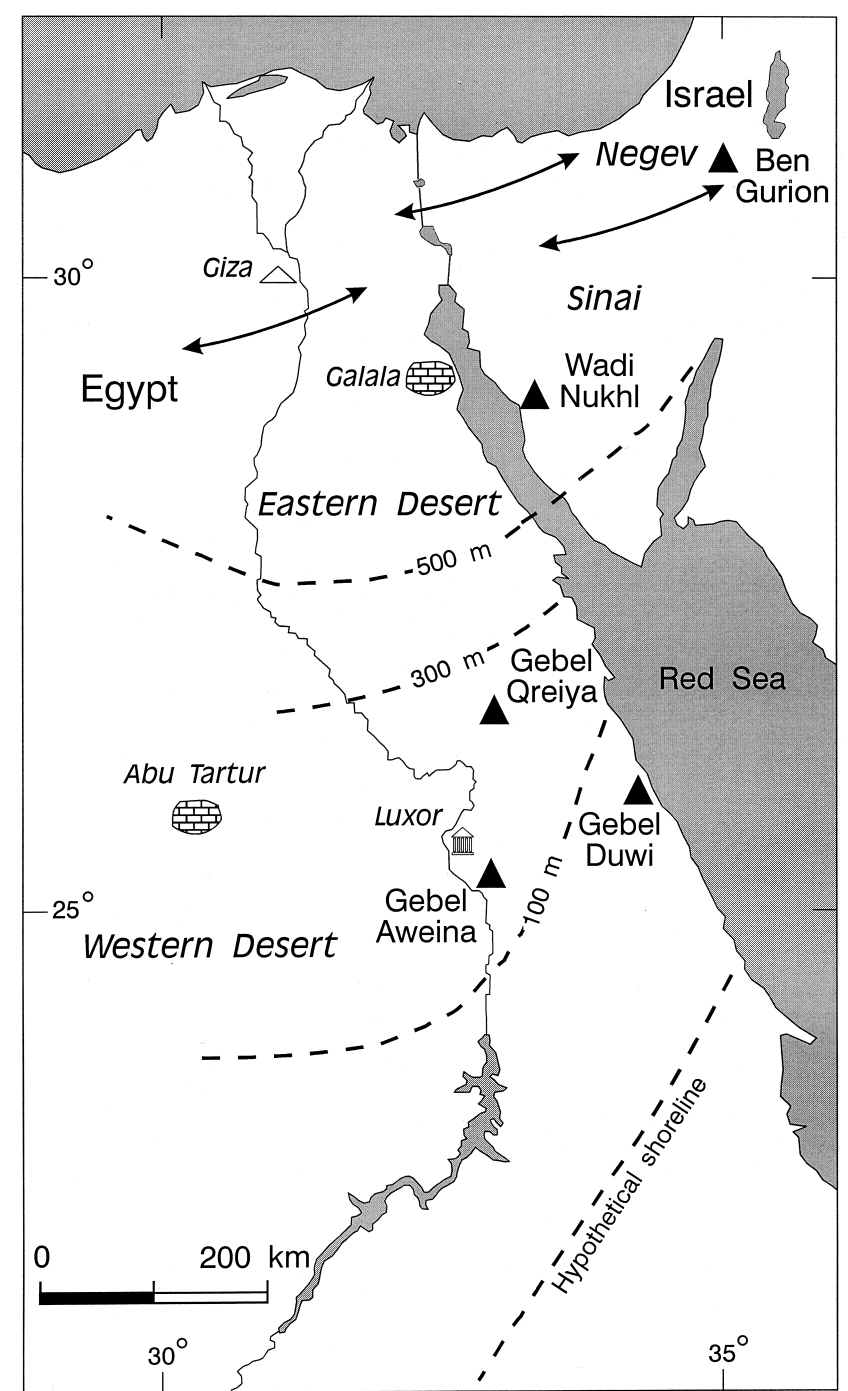

Fig. 1. Location of studied profiles (black triangles) in Egypt and Israel. Palaeobathymetrical reconstruction for the late Palaeocene after Speijer \& Van der Zwaan (1994). Areas with limestone symbols indicate carbonate platforms/ramps. Arrows represent general direction of fold axes (a region of submarine and perhaps emerged swells) of the Sinai-Negev fold-belt.

Gurion (Negev) and Wadi Nukhl (Sinai) sections represent deep basinal depressions (palaeodepth: c. 500-600 m). Neritic deposition characterizes the sections of the Eastern Desert: Gebel Qreiya and Gebel Aweina represent the outer shelf $(150-200 \mathrm{~m})$ and Gebel Duwi the middle shelf $(75-100 \mathrm{~m})$ (Speijer \& Van der Zwaan 1994).

\section{Stratigraphical framework and methods}

The up to $100 \mathrm{~m}$ thick upper Palaeocene to lower Eocene marls and shales in the Eastern Desert are usually termed the Esna Formation. The Esna Formation (sensu stricto) is intercalated between two more calcareous units: the Tarawan Formation (upper Palaeocene) and the Thebes Formation (lower Eocene) (Said 1990a). In southern Israel, the lithostratigraphical equivalents of these formations are, from bottom to top, the chalky Hafir Member, the marly Taqiye Formation (upper part), and the calcareous Mor Formation (e.g. Benjamini 


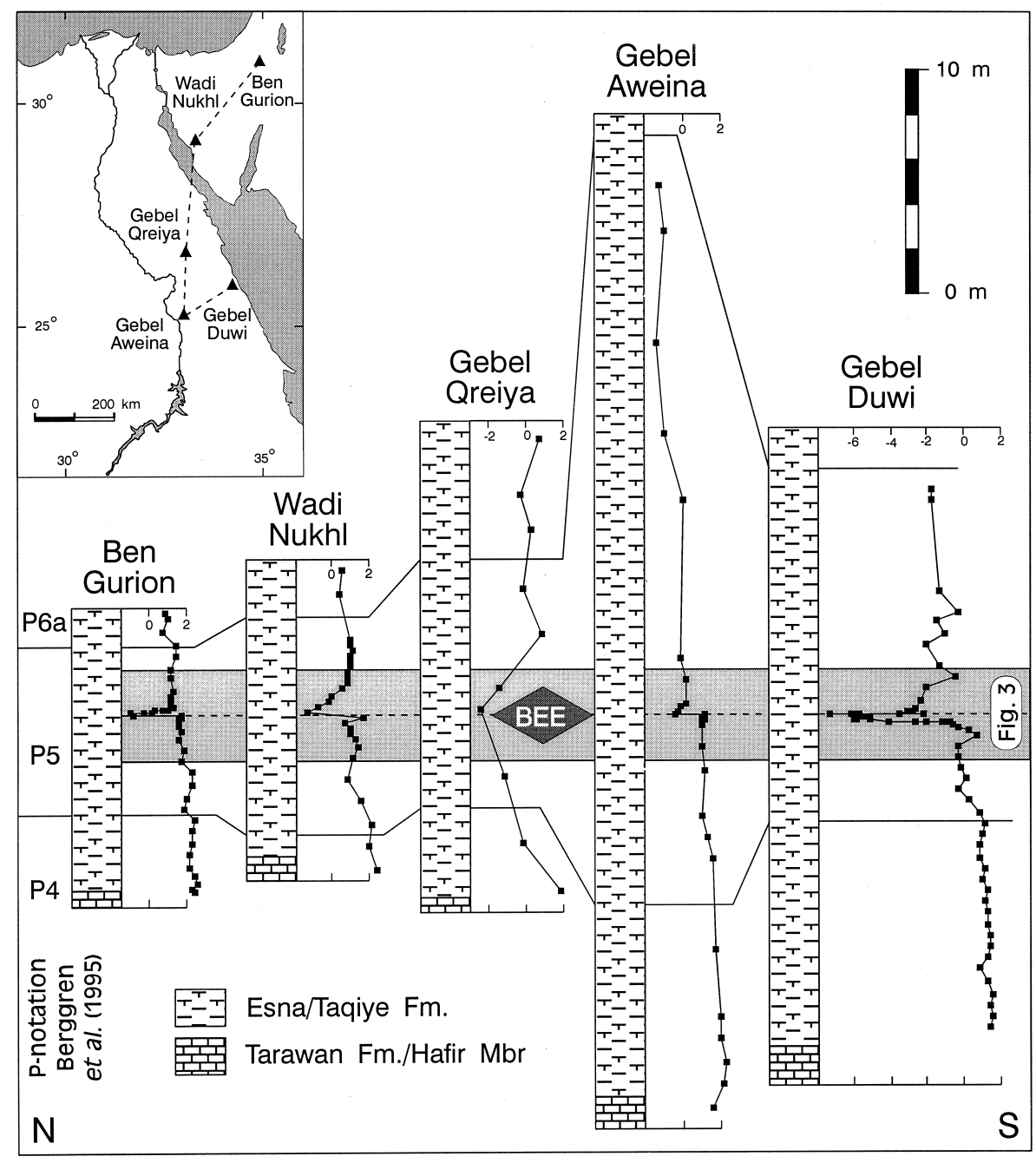

Fig. 2. Stratigraphical correlation of the lower part of the Esna Formation (or equivalent) in Egypt and Israel. Whole-rock $\delta^{13} \mathrm{C}$ excursions coincide with the benthic extinction event (BEE). Note the long-term gradual decrease in $\delta^{13} \mathrm{C}$ values in all sections except Qreiya. Blow-up of the grey interval in Fig. 3.
1992). Both classifications have been adopted in the Sinai due to its recent territorial history. In places where the upper Palaeocene Tarawan Formation (resp. Hafir Member) is absent, the entire Palaeocene to early Eocene succession is often referred to as the Esna Formation (e.g. western Sinai; Said 1990a). The Esna and Taqiye Fms mostly consist of monotonous grey to brown-green marls and shales, containing rich and mostly well-preserved microbiota. In the interval of major biotic changes, however, up to $1 \mathrm{~m}$ thick beds with deviating lithologies (calcarenitic and/or sapropelic) are present.

The stratigraphical interval documented here is bracketed by the base of the Esna Formation, respectively the base of the upper part of the Taqiye Formation (uppermost part of Zone P4) below, and by the P5/P6 zonal boundary (sensu Berggren et al. 1995), above (Fig. 2). Note: apart from the subzonation of Zone P5 as proposed herein, the P-notation for planktic foraminiferal zones refers to the scheme of Berggren et al. (1995).

In Ben Gurion, Qreiya and Duwi, the P4/P5 zonal boundary is determined from the highest occurrence of Globanomalina pseudomenardii. Because this species is usually quite rare in the higher part of its stratigraphical range in the Middle East, this zonal boundary is approximated in the other sections by the lowest occurrence of M. subbotinae (Berggren et al. 1995). Since the Palaeocene-Eocene boundary is currently still defined as the base of the Ypresian (a level within Zone P6; Berggren \& Aubry 1996), the entire studied interval is to be considered as the upper part of the upper Palaeocene. For reasons indicated above, we refrain from estimating numeric temporal relationships.

For Duwi, Aweina and Ben Gurion we studied highresolution (centimetre scale) sample sets across the $\delta^{13} \mathrm{C}$ excursion and the benthic extinction. For Nukhl and Qreiya, only medium-, respectively low- resolution $(25-200 \mathrm{~cm}$ sample spacing) sets were available. The samples were processed according to standard micropalaeontological procedures (e.g. Speijer et al. 1996). Stratigraphical and compositional data of the foraminiferal assemblages were determined qualitatively, and quantitatively respectively (e.g. Speijer et al. 1996).

Whole-rock stable isotopic data were obtained following the procedures of Charisi \& Schmitz (1995). Differential composition and diagenetic overprint of the rocks may have had an influence on the isotopic values. Yet, at least for stratigraphical purposes, the main trends and fluctuations in these curves are considered to be useful. Medium- to high-resolution data of well preserved benthic foraminiferal tests from three of the studied sections (Duwi, Aweina, and Ben Gurion) were published by Schmitz et al. (1996) and Charisi \& Schmitz (1998), but are not incorporated here, since for our purposes, these data do not offer more stratigraphical insight than the whole-rock data. 


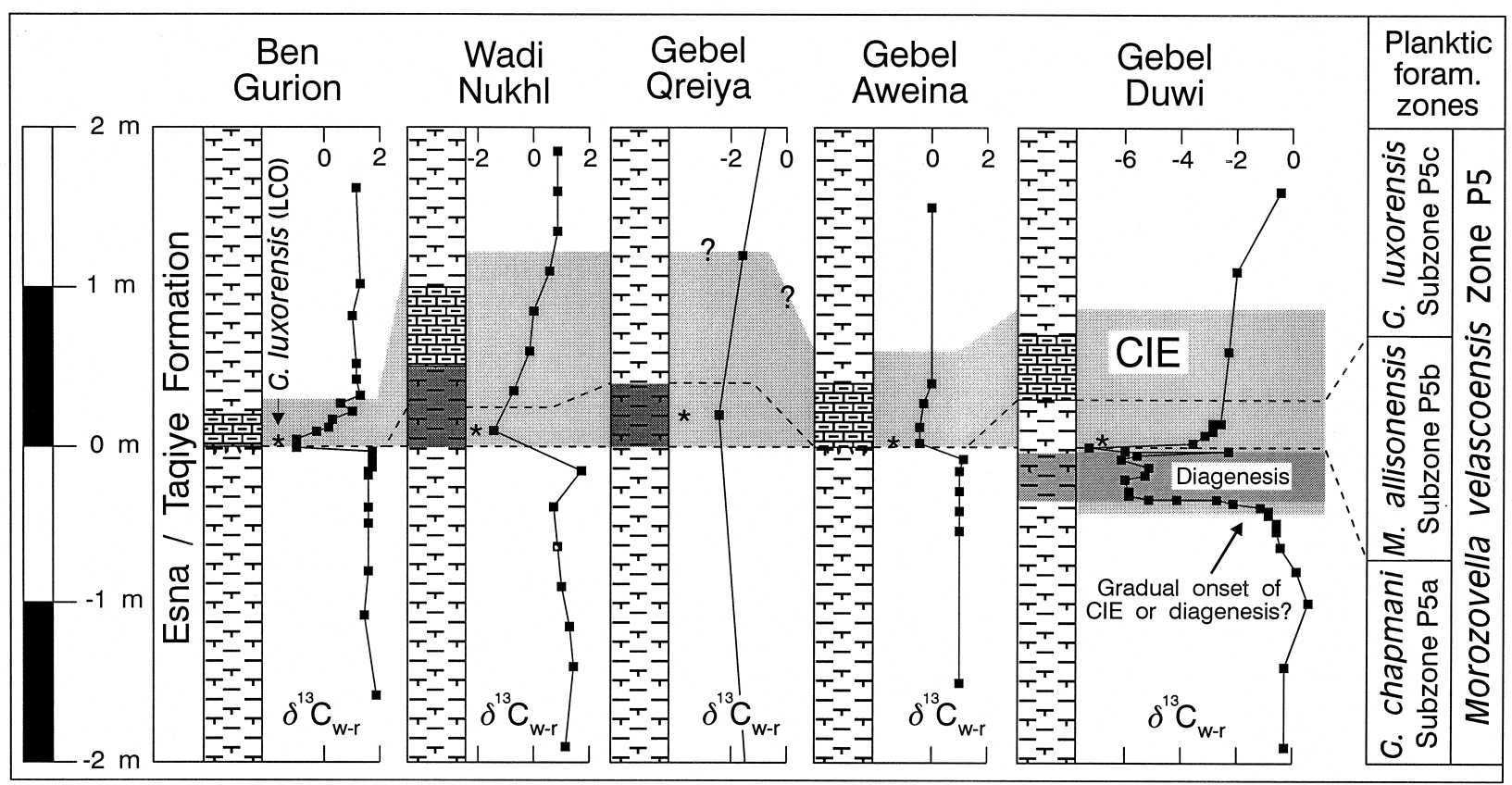

Fig. 3. Detail from correlation plot in Fig. 2 and subzonation of Morozovella velascoensis Zone P5. Three sections (Nukhl, Qreiya, and Duwi) potentially provide the best coverage of the sequence of events associated with the $\delta^{13} \mathrm{C}$ excursion (CIE; light shading) and benthic extinction event. Nukhl and Qreiya show a sapropelic marl bed at this level (darkest shading). The $\delta^{13} \mathrm{C}$ excursion in Ben Gurion and Aweina is truncated by a discontinuity at the base of the calcarenitic bed ('condensed' $\delta^{13} \mathrm{C}$ excursion and absence of Zone P5b). Note that the onset of the $\delta^{13} \mathrm{C}$ excursion in Duwi is difficult to assess, because of diagenetic alteration within a reddish bed (darker shading).

\section{Studied sections}

\section{Ben Gurion}

At Ben Gurion, the benthic extinction event and the $\delta^{13} \mathrm{C}$ excursion $(3 \%$, spanning $30 \mathrm{~cm})$ are located at the base of a calcarenitic marl bed, very rich in planktic foraminifera, about $8 \mathrm{~m}$ above the top of the Hafir Mbr (Fig. 3). The sharp lithological contact and the numerous burrows at the base of the calcarenitic bed indicate a discontinuity, which is also suggested by the abrupt replacement of the G. beccariiformis assemblage by the $N$. truempyi assemblage, without peculiar assemblages in between (Fig. 4). Scattered specimens of G. beccariiformis (dominant below the $\delta^{13} \mathrm{C}$ excursion) within the calcarenitic bed are most likely reworked. The lowest common occurrence of $G$. luxorensis is found in this bed, but M. allisonensis is not present.

\section{Wadi Nukhl}

At Wadi Nukhl, the benthic extinction event coincides with a sapropelic marl bed $(50 \mathrm{~cm}$ thick; dark-brown and laminated with abundant fish remains in the lower half and brownish, unlaminated and pale brown in the upper half), some $6 \mathrm{~m}$ above the base of the Esna Formation. The $\delta^{13} \mathrm{C}$ excursion $(3 \%)$ spans about $1 \mathrm{~m}$, from the base of the sapropelic bed until just above a planktic foraminifera-rich calcarenitic bed. The $G$. beccariiformis assemblage is replaced by the $N$. truempyi assemblage, but two unusual intermediate assemblages (Anomalinoides aegyptiacus and A. zitteli) are observed within the sapropelic bed. These are largely composed of opportunistic neritic taxa, better adapted to highfood/low-oxygen conditions (Speijer et al. 1997). The planktic foraminiferal assemblage within the lower half of the sapropelic bed largely consists of Acarinina (e.g. A sibaiyaensis), but also contains common G. luxorensis and rare Morozovella, including $M$. allisonensis. All foraminifera in this interval are poorly preserved because of compression and dissolution. The top half of the sapropelic bed contains a normal diverse planktic assemblage without $M$. allisonensis.

\section{Gebel Qreiya}

A low-resolution set of samples was available from Gebel Qreiya (Fig. 2). Similar to Wadi Nukhl, the benthic extinction event is situated close to the base of a $40 \mathrm{~cm}$ thick sapropelic marl bed (most likely at its base), some $8 \mathrm{~m}$ above the base of the Esna Formation. The $\delta^{13} \mathrm{C}$-profile shows minimum values within and above the sapropelic bed, but not a distinct excursion. The Angulogavelinella avnimelechi assemblage below the sapropelic bed is replaced by a Bulimina callahani assemblage above. In between, a low diversity Valvulineria sp. assemblage is followed by an $A$. aegyptiacus assemblage. The well preserved planktic assemblage in the sapropelic bed, with a very high planktic/benthic ratio ( $99 \%$ planktic), contains abundant Acarinina (e.g. A. sibaiyaensis) and common G. luxorensis and M. allisonensis.

\section{Gebel Aweina}

At Gebel Aweina, the benthic extinction event and the $\delta^{13} \mathrm{C}$ excursion are situated at the base of a calcarenitic bed with abundant planktic foraminifera, some $17 \mathrm{~m}$ above the base of the Esna Formation. Similar to Ben Gurion, the lithological contact between the calcarenitic bed and the marls below is sharp and penetrated by burrows, indicating a discontinuity. The $\delta^{13} \mathrm{C}$ excursion (1.5\%) spans an interval of about $30 \mathrm{~cm}$ 


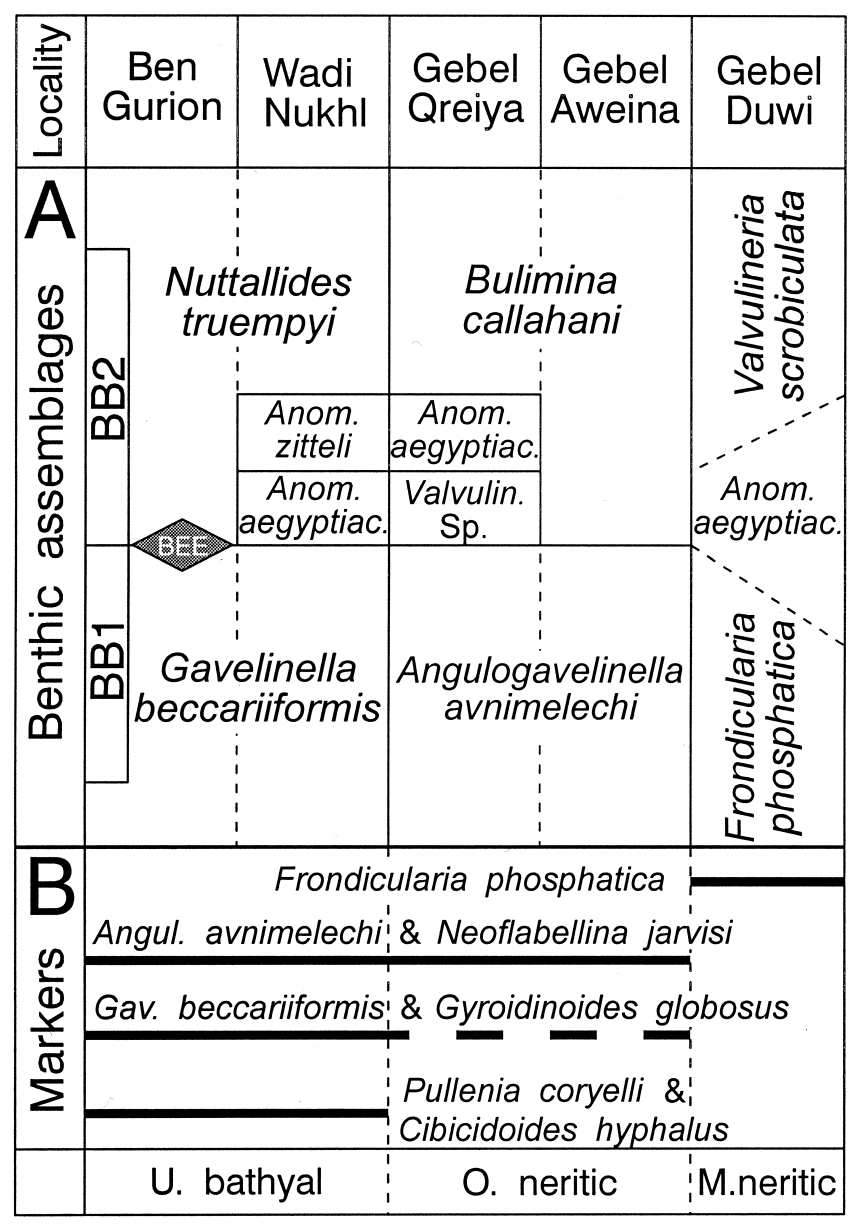

Fig. 4. (a) Schematic representation of the stratigraphical distribution of the main benthic foraminiferal assemblages encountered in the five sections. Note the absence of temporary ('disaster') assemblages following the benthic extinction event (BEE) at Ben Gurion and Aweina. Assemblage transformations at Duwi appear to be gradual (Speijer et al. 1996). BB1 and BB2 indicate corresponding bathyal benthic foraminiferal zones (Berggren \& Miller 1989). (b) Selected taxa that became extinct during the benthic extinction event, ordered by bathymetrical range.

within the calcarenitic bed. At the base of the calcarenitic bed, a B. callahani assemblage replaces an A. avnimelechi assemblage. The lowest common occurrence of G. luxorensis is also at the base of the calcarenitic bed, but there is no unusual planktic foraminiferal assemblage containing M. allisonensis.

\section{Gebel Duwi}

At Gebel Duwi, the exact levels of the onset of the benthic extinction event and the $\delta^{13} \mathrm{C}$ excursion, approximately $15 \mathrm{~m}$ above the base of the Esna Formation, are difficult to establish. Whole-rock $\delta^{13} \mathrm{C}$ values are extremely low ( $8 \%$ excursion) in a $20 \mathrm{~cm}$ thick reddish bed with abundant calcitic pseudomorphs of dolomite rhombs and with a small number of badly preserved foraminifera. These low values are attributed to diagenetic processes. Sharply decreasing $\delta^{13} \mathrm{C}$ values are recorded in the $10 \mathrm{~cm}$ interval below the reddish bed, where all foraminiferal shells show calcite overgrowth, which also suggests diagenetic overprint. Extremely low $\delta^{13} \mathrm{C}$ values are maintained in the $1 \mathrm{~cm}$ thick shale layer overlying the reddish bed. Moderately low $\delta^{13} \mathrm{C}$ values $(-2.6$ to $-3.6 \%$ ) typify the overlying fissile pink marls, which contain excellently preserved foraminifera with relatively little diagenetic infillings, so these values are considered as primary. Below the reddish bed, a relatively diverse benthic assemblage is dominated by $A$. aegyptiacus and contains abundant Frondicularia phosphatica. A gradual impoverishment sets in $4 \mathrm{~m}$ below the reddish bed (Speijer et al. 1996) and accelerates just below it. Within the fissile pink marls, benthic assemblages consist almost exclusively of $A$. aegyptiacus, while $F$. phosphatica became (locally) extinct. Higher up a more diversified $V$. scrobiculata assemblage is present. The fissile marl bed $(c .30 \mathrm{~cm})$ on top of the shale layer yields the same unusual planktic assemblage (with extreme planktic/benthic ratios of up to $99.9 \%$ planktic!) as found at Nukhl and Qreiya, dominated by Acarinina, and with $M$. allisonensis and the lowest common occurrence of G. luxorensis. Detailed nannoplankton studies indicate a paraconformity at about $1 \mathrm{~m}$ above the reddish bed (Schmitz et al. 1996).

\section{Benthic foraminiferal turnover}

In all sections, a turnover in benthic foraminiferal assemblages can be observed coinciding with the $\delta^{13} \mathrm{C}$ excursion and lithological changes. It is most distinct in the deepest sections of Ben Gurion and Nukhl, being marked by a long-term change from a $G$. beccariiformis to a $N$. truempyi assemblage and extinction percentages of $c .45 \%$ (Speijer et al. 1995). Both the change in composition as well as the extinction's magnitude are very similar to turnover characteristics in many deep-sea sites (Kaiho 1994; Thomas 1998). This transition corresponds to the BB1/BB2 zonal boundary in the bathyal biozonation of Berggren \& Miller (1989). At outer neritic depths, a $B$. callahani assemblage replaced an A. avnimelechi assemblage. Very similar and probably correlative turnovers can be observed in other parts of the Egyptian basin as can be inferred from the data of LeRoy (1953) and Luger (1985). The basin-wide extinction of e.g. A. avnimelechi, Neoflabellina jarvisi, and Coryphostoma midwayensis enables a regional subdivision into pre-extinction (Palaeocene) and postextinction (latest Palaeocene) outer neritic assemblages. The extinction percentage of Aweina $(25 \%)$ indicates that the turnover at outer neritic depths was less severe than in the deep sea (Speijer et al. 1995).

A turnover in middle neritic assemblages like that at Gebel Duwi has not yet been observed anywhere else, but possible confirmation in this bathymetrical domain might be sought in southern Egypt. Preliminary data from that region (Luger 1985), however, indicate that the extinction of $F$. phosphatica at Duwi was rather a local phenomenon (Speijer et al. 1996).

The sapropelic or fissile beds with the extremely high planktic/benthic ratios, pointing at oxygen deficiency at the sea-floor, and coinciding with the $\delta^{13} \mathrm{C}$ excursion (Nukhl, Qreiya, Duwi) contain unusual oligotaxic assemblages, dominated by either A. aegyptiacus, Valvulineria sp., Stainforthia sp., or a combination of these. Although the specific compositions of these assemblages vary from place to place, their unique character enables independent regional correlation of the early stages of the post-extinction recovery (Speijer et al. 1997). Detailed centimetre scale sampling reveals that such anomalous assemblages are not present at Aweina or Ben Gurion. 


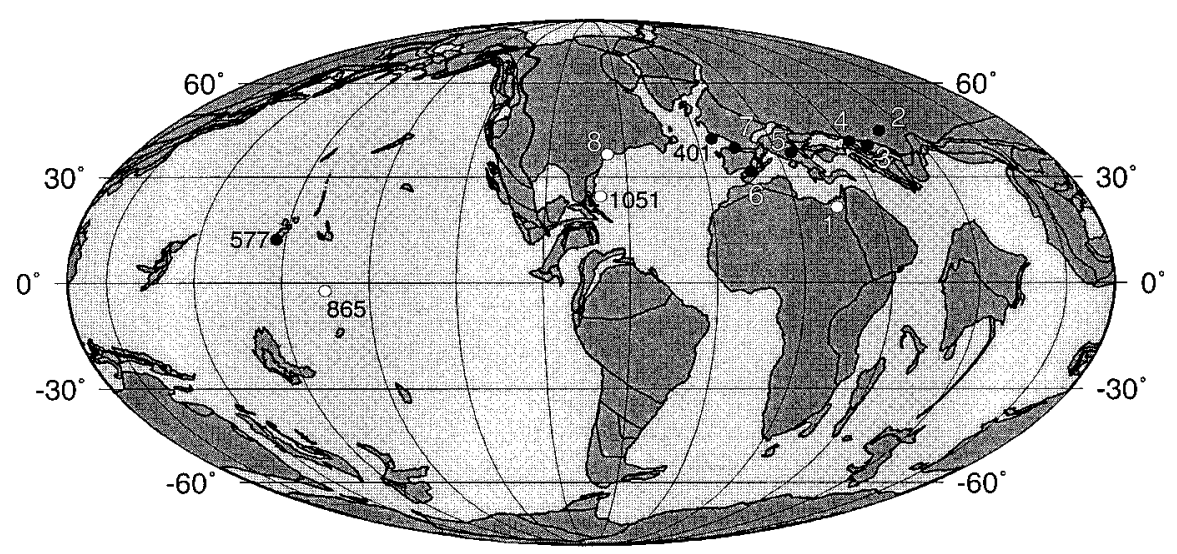

Fig. 5. Palaeobiogeographical distribution of Morozovella allisonensis (white dots) and low to middle latitude sites where this species has not been certified (black dots). 1, Middle East localities presented in this paper; 2, Kaurtakapy, Kazakhstan; 3, Torangly, Turkmenistan; 4, Khieu River, Georgia; 5, Contessa Road, Italy; 6, Caravaca/Alamedilla, southern Spain; 7, Basque country (Zumaya, Trabakua, Ermua), northern Spain; 8, Bass River, New Jersey; and ODP/DSDP sites. Plate-tectonic reconstruction (Mollweide projection) and locations of DSDP and ODP sites (three and four digit numbers) at 55.5 Ma after Hay et al. (1999) using the ODSN Plate Tectonic Reconstruction Service at: http://www.odsn.de/odsn/services/paleomap/paleomap.html.

\section{Subzonation of Morozovella velascoensis Zone P5}

Three Middle East sections (Nukhl, Qreiya, and Duwi) yield a most peculiar Acarinina dominated planktic assemblage in the lower part of the $\delta^{13} \mathrm{C}$ excursion. This assemblage includes rare to common specimens of $M$. allisonensis, but, unlike normal late Palaeocene assemblages in this region, virtually no ordinary Morozovella (e.g. M. velascoensis, M. acuta, and M. occlusa). Peculiar Acarinina dominated assemblages, or increasing numbers of certain Acarinina species have recently been observed in connection with the late Palaeocene thermal maximum in several localities in Spain (Arenillas \& Molina 1996; Lu et al. 1996; Schmitz et al. 1997a), Kazakhstan (Pardo \& Keller 1996), and in various DSDP and ODP Holes (Kelly et al. 1996; Cramer et al. 1997; Pardo et al. 1997). Few of these assemblages, however, contain M. allisonensis. Yet, this species appears to have had a global low to middle latitude distribution (Fig. 5), confined to the $\delta^{13} \mathrm{C}$ excursion interval: in the equatorial Pacific (ODP Hole 865C; Kelly et al. 1996), New Jersey (Bass River, c. $37^{\circ} \mathrm{N}$; Cramer et al. 1997), off Florida (ODP Hole 1051, c. $25^{\circ} \mathrm{N}$; R. D. Norris pers. comm. 1997), and in Egypt $\left(c .25^{\circ} \mathrm{N}\right)$. Considering its presence in quite distinctive palaeoceanographical settings (open ocean-continental margin), M. allisonensis must have had a rather wide ecological tolerance. Nevertheless, it has not been certified in any northern Tethyan succession (questionable in Turkmenistan) or in the eastern North Atlantic. This could suggest a geographical or latitudinal restriction, but its absence could also be explained by unnoticed discontinuities or severe dissolution that coincides with the benthic extinction event in many successions, especially those in Spain (see discussion below).

Our distributional data on $M$. allisonensis confirm the view that $M$. allisonensis rapidly evolved (from $M$. velascoensis) at the onset of the $\delta^{13} \mathrm{C}$ excursion and already became extinct during the later half of it (Kelly et al. 1996, 1998). Consequently, its characteristic morphology, wide and common distribution, and short stratigraphical range make $M$. allisonensis an ideal biostratigraphical marker, providing an unusually accurate tool for correlation, in addition to the $\delta^{13} \mathrm{C}$ excursion. We propose a regional (Middle East) threefold subzonation (Fig. 6) of the Morozovella velascoensis Interval
Zone (P5) as defined by Berggren et al. (1995). Judging from the above mentioned preliminary data from the western Atlantic, we anticipate that this subzonation is generally applicable within conformable successions, free of severe dissolution artefacts, in (sub)tropical regions.

- Zone P5. Morozovella velascoensis Interval Zone, defined by the biostratigraphical interval between the highest occurrence of $G$. pseudomenardii and the highest occurrence of M. velascoensis (Berggren et al. 1995).

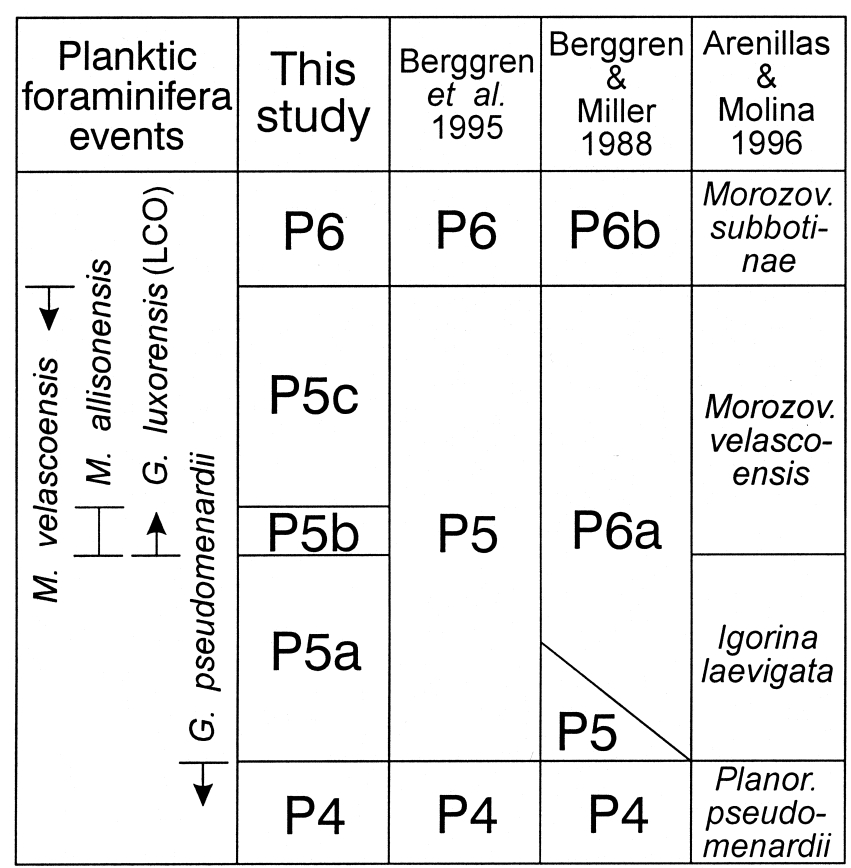

Fig. 6. Correlation of planktic foraminiferal zonation schemes with subzonation of Morozovella velascoensis Zone P5 (Berggren et al. 1995 ) as established in Egypt; considered generally applicable in low to middle-latitude regions. LCO is lowest common occurrence. Not to scale. 
- Subzone P5a. Globanomalina chapmani Interval Subzone, defined by the biostratigraphical interval between the highest occurrence of G. pseudomenardii (or approximated by the lowest occurrence of $M$. subbotinae) and the lowest occurrence of $M$. allisonensis.

- Subzone P5b. Morozovella allisonensis Total Range Subzone, defined by the biostratigraphical interval of the total range of $M$. allisonensis.

- Subzone P5c. Globanomalina luxorensis Interval Subzone, defined by the biostratigraphical interval between the highest occurrence of $M$. allisonensis and the highest occurrence of $M$. velascoensis.

In Middle East sections where M. allisonensis and Subzone P5b cannot be identified because of discontinuities (e.g. Aweina and Ben Gurion) or insufficient resolution, the lowest common occurrence of $G$. luxorensis enables the distinction between the P5a and P5c subzones. In other (sub)tropical regions, alternative markers may enable a subzonation of Zone P5 in the absence of $M$. allisonensis. For example, in Alamedilla, southern Spain, the highest occurrence of Igorina laevigata is considered to enable a twofold (pre- and post-extinction) subdivision (Arenillas \& Molina 1996). The I. laevigata Zone of Arenillas \& Molina (1996) corresponds to Subzone P5a as proposed here, while their M. velascoensis Zone corresponds to Subzone P5c (possibly including beds correlative with Subzone P5b). (Note, however, that unlike various other workers these authors distinguish I. laevigata from I. albeari, which ranges beyond the base of the $\delta^{13} \mathrm{C}$ excursion in Spain; Canudo et al. 1995; Arenillas \& Molina 1996.)

Kelly et al. (1996, 1998) suggested that besides $M$. allisonensis also A. sibaiyaensis and M. africana (recorded as $A$. africana by Arenillas \& Molina 1996) evolved rapidly at the onset of the $\delta^{13} \mathrm{C}$ excursion. El-Naggar (1966), who originally described the latter two taxa, however, documented these taxa from a $20 \mathrm{~m}$ thick upper Palaeocene interval. In his tabulation, they have their lowest occurrence at the top of the Tarawan Fm (base of ' $M$. velascoensis Zone' according to El-Naggar, but Zone P4 according to our data) and range up to $12 \mathrm{~m}$ above the base of the Esna Formation, which in the profile we measured at Aweina would be up to some $6 \mathrm{~m}$ below(!) the $\delta^{13} \mathrm{C}$ excursion. We can confirm the observations of El-Naggar by the presence of scattered specimens of $A$. sibaiyaensis and $M$. africana in the lowermost part of the Esna Formation at Aweina. In Alamedilla, Spain, these taxa range from slightly to well above the benthic extinction event (A. sibaiyaensis up into Zone P6b; Arenillas \& Molina 1996). Thus neither of these taxa evolved or became extinct at the onset of, or respectively close to, the $\delta^{13} \mathrm{C}$ excursion. Rather, these taxa dispersed, possibly from populations restricted to the (southern?) Tethys, through changing oceanographical conditions at the onset of the $\delta^{13} \mathrm{C}$ excursion. So in general, $M$. africana and $A$. sibaiyaensis cannot serve as alternative biostratigraphical markers to define Subzone P5b in the absence of $M$. allisonensis. Rather, this absence in low to middle latitude profiles points to an incomplete coverage of the $\delta^{13} \mathrm{C}$ excursion, irrespective of eventual increases in the proportion of Acarinina.

\section{$\delta^{13} \mathrm{C}$ patterns and discontinuities in Middle East sections}

All studied Middle-East sections show $\delta^{13} \mathrm{C}$ values of around $2 \%$ at the base of Esna Formation (Fig. 2). These are followed by a gradual negative trend (excluding the somewhat ambiguous data of Qreiya, which are not considered further in this section) up to the P5/P6 zonal boundary of about $1 \%$ o in the deepest hemipelagic sections (Ben Gurion and Nukhl) to $3.5 \%$ in the neritic sections of Aweina and Duwi. This trend reflects in part the well-known decline in marine (oceanic) $\delta^{13} \mathrm{C}$ values (e.g. Corfield 1994). The deepest sections show the least deviation $(1-2 \%$ ) from oceanic surface records (Charisi \& Schmitz 1995, 1998). The inter-site differences appear to relate to palaeodepth and/or distance to shore, indicating increased restriction from the open ocean towards shallower depths and perhaps greater influence from the Arabian-Nubian shield. The consistent offset between deeper and shallow sites suggests that this indeed reflects a palaeoevironmental signal rather than diagenetic overprint (see also results on foraminiferal calcite in Charisi \& Schmitz 1995, 1998).

Superimposed on this general negative trend all sections show a sharp $1-4 \%$ negative $\delta^{13} \mathrm{C}$ excursion (disregarding the reddish interval of Duwi). The tight coincidence with profound biotic changes strongly suggests that the $\delta^{13} \mathrm{C}$ excursions correlate, at least in part, with the $\delta^{13} \mathrm{C}$ excursion in deep-sea sections. Three sections (Nukhl, Qreiya, Duwi) show an apparently conformable succession across the benthic extinction event and yield highly unusual excursion biota. The sections of Ben Gurion and Aweina display a discontinuity at the base of the calcarenitic bed and it is therefore not surprising that there is no evidence of any short-lived excursion biota. Yet, these sections also show $\delta^{13} \mathrm{C}$ excursions coinciding with turnovers in the benthic communities. This indicates that these $\delta^{13} \mathrm{C}$ excursions probably represent the later stages of the $\delta^{13} \mathrm{C}$ excursion, although the large amplitude of the excursion in the Ben Gurion section may appear to contradict this interpretation.

The discontinuities at Aweina and Ben Gurion also suggest that part of the stratigraphical record below the $\delta^{13} \mathrm{C}$ excursion is missing. To what extent the record below the $\delta^{13} \mathrm{C}$ excursion is incomplete, cannot be determined from our data. Furthermore, the condensed nature of the sections of Ben Gurion, Nukhl, and Qreiya, particularly the interval between the benthic extinction event and the P5/P6a zonal boundary, may either point to incomplete records or to (for a continental margin unlikely) slow sedimentation rates. Further assessment of potential discontinuites outside the $\delta^{13} \mathrm{C}$ excursion interval can only be addressed after full integration of calcareous nannoplankton data.

\section{Completeness across the $\delta^{13} \mathrm{C}$ excursion in (sub)tropical successions}

An integrated stratigraphical framework based on highest occurrences of benthic foraminifera, the $\delta^{13} \mathrm{C}$ excursion, and the unique distribution of $M$. allisonensis provides a powerful tool for assessment of the stratigraphical completeness across the $\delta^{13} \mathrm{C}$ excursion at low to middle latitudes. The stratigraphy of a number of sections and bore holes in open marine (sub)tropical settings has been studied in sufficient detail to be evaluated against the results from the Middle East.

\section{Northern Tethys}

Sections in the northern Tethys being studied in detail are the hemipelagic and bathyal successions of Alamedilla, and Caravaca in southern Spain, and several outcrops near Gubbio in central Italy. Lu et al. (1996) documented a $2 \%{ }^{13} \mathrm{C}$ 
excursion, measured on a seemingly continuous profile of $M$. subbotinae in the Alamedilla section. This excursion coincides with the benthic extinction event and with an increase in compressed Acarinina, including $A$. sibaiyaensis. These authors argued for an expanded profile spanning the $\delta^{13} \mathrm{C}$ excursion, as compared to deep-sea sections. Arenillas \& Molina (1996), studying the same sample set of Alamedilla, observed the sharp increase in Acarinina too, but situated it above a $30 \mathrm{~cm}$ thick decalcified red clay bed overlying the benthic extinction event. Our own preliminary observations on this section confirm the latter presentation. Despite the greater abundance of Acarinina, the planktic assemblage above the clay layer, composed of 30-50\% Morozovella (Arenillas \& Molina 1996), is quite distinct from the anomalous planktic assemblages from Egypt and does not contain M. allisonensis, so Subzone P5b cannot be identified here, but may be concealed by the decalcified clay bed.

The well-known Caravaca section shows a similar sequence as Alamedilla. Isotopic profiles on benthic foraminifera show an expanded $3 \% 0 \delta^{13} \mathrm{C}$ excursion, the base of which more or less coincides with the benthic extinction event in a $2 \mathrm{~m}$ thick largely decalcified clay bed (Molina et al. 1994; Ortiz 1995). The interval between the benthic extinction event and the highest occurrence of $M$. velascoensis is as expanded/ condensed (6 m) as that of Alamedilla (Molina et al. 1994; Arenillas \& Molina 1996). The planktic foraminiferal assemblages recovered directly above the clay are similar to the ones below, showing no peculiarities (Canudo et al. 1995). So despite the well-expressed $\delta^{13} \mathrm{C}$ excursion, it is unlikely that the early part of the $\delta^{13} \mathrm{C}$ excursion is represented in this profile. Judging from the preservation of the foraminifera and from the return to stable post-excursion $\delta^{13} \mathrm{C}$ values as high up as within Zone P6a, diagenetic overprint probably plays an important role here.

In the classical Contessa Highway and Bottaccione sections near Gubbio in the Apennines, Italy, the Palaeocene-Eocene boundary interval is partly covered, respectively slumped (Corfield et al. 1991; Galeotti et al. 1998). The Contessa Road section is considered to provide a better coverage of the Palaeocene-Eocene transition (Galeotti et al. 1998). Unfortunately, the predominance of indurated limestones hampers the recovery of continuous calcareous-microfossil records and the section is also rather condensed, similar to oceanic records. A modest $1 \%{ }^{13} \mathrm{C}$ excursion (whole rock, low resolution) is found $20 \mathrm{~cm}$ above an anomalous $2 \mathrm{~cm}$ thick red clay bed, which marks the benthic extinction event (unpublished data of R.P.S.) and distinct changes in the agglutinated foraminifera assemblage (Galeotti et al. 1998). Judging from the low amplitude of the excursion, this level might represent the upper part of the $\delta^{13} \mathrm{C}$ excursion. Morozovella allisonensis has not been identified here and considering the predominant lithology it is unlikely it will be, even if it were present.

Pilot studies were performed on sections in the south of the former Soviet Union ('Peri-Tethys'). In the sections of Khieu River (Georgia), Torangly (Turkmenistan), and Kaurtakapy (Kazakhstan), the benthic extinction event coincides with the base of dark (sapropelic) marl/shale beds within Zones P5 and/or NP9 (Muzylöv et al. 1995; Berggren \& Aubry 1996; Pardo \& Keller 1996; Speijer et al. 1997). A $\delta^{13}$ C profile of the Kaurtakapy profile suggests the presence of the $\delta^{13} \mathrm{C}$ excursion and an incursion of warm surface water dwellers including $A$. sibaiyaensis (Pardo \& Keller 1996). In the Torangly section, a few specimens of $G$. luxorensis as well as two poorly preserved specimens that resemble $M$. allisonensis were identified within a very small sample from the sapropelic bed. This, together with the similarity between lithological successions and extinction and recovery patterns of the benthic assemblages of Torangly and Nukhl, suggests that perhaps the same stratigraphical interval is represented (Speijer et al. 1997). More detailed studies are needed to fully explore the stratigraphical and palaeoenvironmental potential of these sections.

\section{Eastern North Atlantic}

The Palaeocene-Eocene transition has been studied intensively in several sections in the Basque country, Spain (e.g. Zumaya and Trabakua) and in DSDP Hole 401 in the Bay of Biscay. The Basque sections, representing slope and basin settings, yield expanded Palaeocene-Eocene transitions, which in part results from the presence of turbidites. The benthic extinction event in these sections is situated at the base of a several metre thick clay interval strongly affected by dissolution (e.g. Canudo et al. 1995; Orue-Etxebarria et al. 1996; Schmitz et al. 1997a). Carbon isotopes have been measured on whole-rock carbonate (Schmitz et al. 1997a) and on benthic foraminifera (Canudo et al. 1995) from Zumaya. The whole-rock data, particularly from limestones, are probably more reliable inasmuch as the main trends are concerned, because the foraminifera are strongly recrystallized. Highly negative whole-rock $\delta^{13} \mathrm{C}$ values in the clay interval, however, reflect the composition of diagenetic calcite veins, rather than a mixture of microfossils (Schmitz et al. 1997a). A most interesting feature of the Zumaya profile is the gradual $1.5 \% \delta^{13} \mathrm{C}$ excursion over a $35 \mathrm{~cm}$ thick interval (not to be confused with the long-term gradual decrease from Zone P4 to P5), below the benthic extinction event (base of the clay), which is accompanied by a modest increase in Acarinina (Schmitz et al. 1997a). The $4 \mathrm{~m}$ thick overlying clay contains a fossiliferous interval, showing a further increase in Acarinina, but without M. allisonensis (Canudo et al. 1995; Schmitz et al. 1997a). Other Basque sections (Trabakua and Ermua) basically show the same type of sequence as Zumaya, but initial results on these sections (Orue-Etxebarria et al. 1996) could not yet corroborate the peculiar finds of Zumaya (more detailed studies are in progress). Thus the true meaning of the preextinction isotopic shift remains enigmatic (see Schmitz et al. $1997 a$ for detailed discussion).

Benthic and surface-dwelling planktic foraminifera (M. subbotinae) from DSDP Hole 401, Meriadzek Terrace, Bay of Biscay, show a $1 \% 0$, and respectively $2 \% \delta^{13} \mathrm{C}$ excursion coinciding with the benthic extinction event (Pak \& Miller 1992; Pardo et al. 1997). The planktic assemblage shows a persistent turnover in Zone P5 and an increase of warm surface dwellers (Acarinina and Morozovella) in conjunction with the $\delta^{13} \mathrm{C}$ excursion (Pardo et al. 1997). Sample spacing across the $\delta^{13} \mathrm{C}$ excursion of Hole 401 in Pak \& Miller (1992) and Pardo et al. (1997) was relatively wide $(20-60 \mathrm{~cm})$ as compared to the $1-6 \mathrm{~cm}$ spacings in the studies on ODP Holes 690B and 865C (Kennett \& Stott 1991; Kelly et al. 1996), which may explain the weaker isotopic excursion and the absence of an anomalous planktic assemblage with $M$. allisonensis. Alternatively, absence of an anomalous assemblage could also point to a discontinuity as suggested by preliminary calcareous nanoplankton studies (Berggren \& Aubry 1996).

\section{Pacific}

ODP Hole 865C, Allison Guyot, provides the best developed $\delta^{13} \mathrm{C}$ excursion (3\%) in the Pacific (Kelly et al. 1996). The 
presence of the anomalous planktic assemblage including $M$. allisonensis within the $\delta^{13} \mathrm{C}$ excursion enables accurate biostratigraphical correlation between the Pacific and the Tethys, independently of $\delta^{13} \mathrm{C}$ signatures. The most intensively studied lower Paleogene deep-sea succession in the Pacific, however, is in DSDP Hole 577 (Shatsky Rise, subtropical North Pacific). Here, Miller et al. (1987) proposed the thought-provoking relation between the benthic extinction event, bottom water temperature rise, and oceanic circulation and climatic changes near the Palaeocene-Eocene boundary. Initial studies on Hole 577 only revealed the long-term $\delta^{13} \mathrm{C}$ decline, not the $\delta^{13} \mathrm{C}$ excursion (e.g. Shackleton et al. 1985; Miller et al. 1987). A high-resolution study (Pak \& Miller 1992) showed a $1 \%{ }^{13} \mathrm{C}$ shift (benthic), coinciding with the benthic extinction event, just below the P5/P6 zonal boundary. According to Lu \& Keller (1995) the benthic extinction event also coincides with the top of a planktic foraminiferal turnover interval. These authors indicated, however, that the true magnitude of this turnover could be artificially amplified because of truncation through incomplete core recovery (Lu \& Keller 1995, caption fig. 5). Aubry (1998) thoroughly scrutinized the quality of the cores of Hole 577 spanning the Palaeocene-Eocene transition, studied the calcareous nanoplankton, and re-evaluated all other available stratigraphical data. She concluded that part of this interval is poorly recovered indeed and probably also comprises a discontinuity at the level of the benthic extinction event and thus regarded all biotic and geochemical events indicated by earlier workers as pseudo-events, resulting from truncation on both ends of the $\delta^{13} \mathrm{C}$ excursion. That no planktic excursion taxa were found, despite the very close sample spacing ( $5 \mathrm{~cm}$; Lu \& Keller 1995), substantiates the interpretation of Aubry (1998). Other discontinuities higher up in NP9 and NP10 indicate that this hole provides a rather poor representation of the Paleocene-Eocene transition (Aubry 1998). It is somewhat ironic, that the birth of a challenging and basically valid hypothesis had its impetus from a rather incomplete succession across the crucial interval.

\section{Summary}

In all currently well-documented sections in Spain, a dissolution facies of variable thickness with no, or only agglutinated, foraminifera tops the highest occurrence of the G. beccariiformis assemblage. In some sections (Alamedilla, Zumaya) a distinct increase of Acarinina has been observed close to the benthic extinction event (Arenillas \& Molina 1996; Lu et al. 1996; Schmitz et al. 1997a). In Alamedilla, this includes high numbers of $A$. sibaiyaensis (Arenillas \& Molina 1996; Lu et al. 1996). The absence of M. allisonensis, however, indicates that Subzone P5b is not represented, but possibly the later part of the $\delta^{13} \mathrm{C}$ excursion is recorded. The onset of the $\delta^{13} \mathrm{C}$ excursion (and correlative of Subzone $\mathrm{P} 5 \mathrm{~b}$ ) may be hidden within the clay bed at Alamedilla and perhaps it does so in Caravaca and the Basque sections too (Zumaya possibly below it). However, in the absence of calcareous foraminifera and primary calcite in general, there is currently no possibility to accurately correlate these clay beds to the best records spanning the $\delta^{13} \mathrm{C}$ excursion elsewhere. Consequently, these clay beds are as problematical as physical discontinuities (Aubry 1998). On the other hand, if it can be certified that the rare to frequent occurrences of calcareous nannofossils in the clays from Caravaca and Alamedilla (Monechi \& Angori 1998) do not result from contamination, then these could contribute to solving part of this problem.
In middle latitude localities (e.g. DSDP Site 401 and Kaurtakapy), which possibly lie beyond the biogeographical distribution of $M$. allisonensis, a correlation with the early part of the $\delta^{13} \mathrm{C}$ excursion based on the appearance of Acarinina still requires verification, either in the form of a more pronounced isotopic excursion through higher resolution sampling, or possibly by means of detailed calcareous nannofossil studies.

In other successions (Aweina, Ben Gurion, ODP Hole 577, DSDP Hole 401?) valuable information on the $\delta^{13} \mathrm{C}$ excursion and associated events is lost within discontinuities or coring disturbances of various dimensions.

The low-middle latitude sections on land that appear to span the $\delta^{13} \mathrm{C}$ excursion most completely, seem to be Nukhl, Qreiya and Duwi in Egypt. Clearly, the former two sections still require high-resolution accounts, but it is very promising that despite the low resolution a precise correlation to ODP Hole $865 \mathrm{C}$ is possible at all. In all other low-middle latitude land sections known to date, the stratigraphical interval correlative with Subzone P5b is either absent or possibly distorted by a dissolution facies. For high-resolution correlations on millennium scales that are probably associated with the onset of the $\delta^{13} \mathrm{C}$ excursion and the benthic extinction event, these sections are unsuitable. Nevertheless, these sections are indispensable for creating the integrated stratigraphical framework corresponding to longer time intervals in which to tie in the short-term late Palaeocene events.

\section{Conclusions}

In all Middle East sections studied, irrespective of their palaeobathymetrical positions, the level of latest Palaeocene global change can be monitored lithologically, isotopically and using foraminifera.

Integration of our data clearly shows that a well-expressed $\delta^{13} \mathrm{C}$ excursion does not necessarily indicate a complete coverage of the $\delta^{13} \mathrm{C}$ excursion: in the Aweina and Ben Gurion sections, the lowermost part of the $\delta^{13} \mathrm{C}$ excursion and the upper pre- $\delta{ }^{13} \mathrm{C}$ excursion record are truncated by a discontinuity.

The short stratigraphical range of $M$. allisonensis in the lower part of the $\delta^{13} \mathrm{C}$ excursion enables a threefold subdivision of Zone P5 (Morozovella velascoensis Zone): Subzone P5a (Globanomalina chapmani Subzone), Subzone P5b (Morozovella allisonensis Subzone), and Subzone P5c (Globanomalina luxorensis Subzone).

In the Middle East, sections with a sapropelic or fissile marl bed in the lower part of the $\delta^{13} \mathrm{C}$ excursion (Subzone P5b) with its unique biotic features provide the best registration of the sequence of events in this region.

- Latest Biochron P5a: gradual deterioration of the benthic assemblage preceding the benthic extinction event at middle neritic depths (Duwi). Apparently stable assemblages in deeper successions.

- Biochron P5b: basin-wide onset of the $\delta^{13} \mathrm{C}$ excursion associated with the benthic extinction event, oxygen deficiency, spreading of opportunistic shallow water benthic taxa, Acarinina domination, near absence of Morozovella, evolution of $M$. allisonensis, and first blooming of $G$. luxorensis.

- Earliest Biochron P5c: gradual restoration of $\delta^{13} \mathrm{C}$ values and eventually termination of the excursion, return of 
diversified planktic assemblages with numerous Morozovella, but extinction of $M$. allisonensis, settlement of stable and diverse benthic assemblages, restoration of bathymetrical biotic zonation.

Morozovella allisonensis is an excellent stratigraphical marker for correlation between distinctive environmental regimes in the (sub)tropical Pacific, Atlantic, and Tethys. Its absence in low to middle latitude sections results from discontinuities or from severe dissolution within the $\delta^{13} \mathrm{C}$ excursion interval.

Judging from the condensed nature of the sections that have the best developed short-term sequence of events (i.e. including Subzone P5b), it is rather unlikely that any of these sections yields a complete coverage of Zone P5.

A full account of the chronology of the long- and short-term sequence of latest Palaeocene events in the Middle East requires further integration of high-resolution data from all sections, preferably including calcareous nannofossils, clay mineralogy, and magnetostratigraphy.

We thank W. A. Berggren and an anonymous reviewer for their comments, D. Pirrie for editorial improvements and I. Arenillas for biostratigraphic data. We acknowledge The Humboldt Foundation and The Bank of Sweden Tercentenary Foundation for financial support.

\section{References}

Arenillas, I. \& Molina, E. 1996. Biostratigrafía y evolucíon de las asociaciones de foraminíferos planctónicos del tránsito Paleoceno-Eoceno en Alamedilla (Cordilleras Béticas). Revista Española de Micropaleontología, 18, 75-96.

AubRY, M.-P. 1998. Stratigraphic (dis)continuity and temporal resolution of geological events in the upper Paleocene-lower Eocene deep-sea record. In: Aubry, M.-P., Lucas, S. \& Bergaren, W.A. (eds) Late Paleocene-Early Eocene Climatic and Biotic Events in the Marine and Terrestrial Records. Columbia University Press, New York, 37-66.

—, Berggren, W.A., Stott, L.D. \& Sinha, A. 1996. The upper Paleocenelower Eocene stratigraphic record and the Paleocene-Eocene boundary carbon isotope excursion; implications for geochronology. In: KNOx, R.W.O.B., Corfield, R.M. \& DunAy, R.E. (eds) Correlation of the early Paleogene in Northwest Europe. Geological Society, London, Special Publications, 101, 353-380.

BARAZI, N. \& Kuss, J. 1987. Southern outcrops of marine Lower Teriary carbonate rock in NE-Africa (Gebel Abyad, Sudan). Geologische Rundschau, 76, 529-537.

Bartov, Y. \& Steinitz, G. 1977. The Judea and Mount Scopus groups in the Negev and Sinai with trend surface analysis of the thickness data. Israel Journal of Earth Sciences, 26, 119-148.

Benjamini, C. 1992. The Paleocene-Eocene boundary in Israel - a candidate for the boundary stratotype. In: Luterbacher, H. (ed.) Paleogene Stages and their Boundaries. Neues Jahrbuch für Geologie und Paläontologie, Abhandlungen, 186, 49-61.

Berggren, W.A. \& Aubry, M.-P. 1996. A late Paleocene-early Eocene NW European and North Sea magnetobiochronological correlation network. In: Knox, R.W.O.B., Corfield, R.M. \& Dunay, R.E. (eds) Correlation of the early Paleogene in Northwest Europe. Geological Society, London, Special Publications, 101, 309-352.

_ \& Miller, K.G. 1989. Cenozoic bathyal and abyssal calcareous benthic foraminiferal zonation. Micropaleontology, 35, 308-320.

—, Kent, D.V., Swisher, III, C.C. \& Aubry, M.-P. 1995. A revised Cenozoic geochronology and chronostratigraphy. In: BergGren, W.A., Kent, D.V., Aubry, M.-P. \& Hardenbol, J. (eds) Geochronology, Time Scales and Global Stratigraphic Correlation. Society for Economic Paleontologists and Mineralogists, Special Publication, 54, 129-212.

Canudo, J.I., Keller, G., Molina, E. \& Ortiz, N. 1995. Planktic foraminiferal turnover and $\delta^{13} \mathrm{C}$ isotopes across the Paleocene-Eocene transition at Caravaca and Zumaya, Spain. Palaeogeography, Palaeoclimatology, Palaeoecology, 114, 75-100.
Charisi, S.D. \& Schmitz, B. 1995. Stable $\left(\delta^{13} \mathrm{C}, \delta^{18} \mathrm{O}\right)$ and strontium $\left({ }^{87} \mathrm{Sr} /{ }^{86} \mathrm{Sr}\right)$ isotopes through the Paleocene at Gebel Aweina, eastern Tethyan region. Palaeogeography, Palaeoclimatology, Palaeoecology, 116, 103-129.

_ \& 1998. Paleocene to early Eocene paleoceanography of the Middle east: The $\delta^{13} \mathrm{C}$ and $\delta^{18} \mathrm{O}$ isotopes from foraminiferal calcite. Paleoceanography, 13, 106-118.

Corfield, R.M. 1994. Palaeocene oceans and climate; an isotopic perspective. Earth Science Reviews, 37, 225-252.

—, Cartlidge, J.E., Premoli-Silva, I. \& Housley, R.A. 1991. Oxygen and carbon isotope stratigraphy of the Palaeogene and Cretaceous limestones in the Bottaccione Gorge and the Contessa Highway sections, Umbria, Italy. Terra Nova, 3, $414-422$.

Cramer, B.S., Aubry, M.-P., Olsson, R.K., Miller, K.G. \& Wright, J.D. 1997. Stratigraphic and climatic implications of a continuous, thick Paleocene/Eocene boundary, Bass River, NJ (ODP Leg 174AX). AGU Fall Meeting 1997, F363.

EL-NAGGAR, Z.R.M. 1966. Stratigraphy and planktonic foraminifera of the upper Cretaceous-lower Tertiary succession in the Esna-Idfu region, Nile Valley, Egypt, U.A.R. Bulletin of the British Museum (Natural History), Geology Supplement, 2, 1-291.

Galeotti, S., Angori, E., Coccioni, R., Ferrari, G., Monechi, S., Morettini, E. \& Premoli Silva, I. 1998. Integrated biostratigraphy and isotope geochemistry across the Paleocene/Eocene boundary in a classical Tethyan setting: The Contessa-Road section. In: Rey, J. \& Ronchini, F. (eds) La limite Paléocène-Éocène en Europe: Événements et Corrélations. Strata, Actes du Laboratoire de Géologie Sédimentaire et Paléontologie de l'Université Paul Sabatier, Toulouse, Série 1: Communications, 9, 49-52.

Gibson, T.G., Bybell, L.M. \& Owens, J.P. 1993. Latest Paleocene lithologic and biotic events in neritic deposits of southwestern New Jersey. Paleoceanography, 8, 495-514.

Gingerich, P.D. 1980. Evolutionary patterns in early Cenozoic mammals. Annual Review of Earth and Planetary Sciences, 8, 407-424.

Hay, W.W., DeConto, R., Wold, C.N., Wilson, K.M., Voigt, S., Schulz, M., Wold-Rossby, A., Dullo, W.C., Ronov, A.B., Balukhovsky, A.N. \& SöDING, E. 1999. An alternative global Cretaceous paleogeography. In: Barrera, E. \& Johnson, C. (eds) The Evolution of Cretaceous Ocean/ Climate Systems. Geological Society of America Special Publication, 332, in press.

KaIHO, K. 1994. Planktonic and benthic foraminiferal extinction events during the last 100 m.y. Palaeogeography, Palaeoclimatology, Palaeoecology, 111, $45-71$.

Kelly, D.C., Bralower, T.J. \& ZaChos, J.C. 1998. Evolutionary consequences of the latest Paleocene thermal maximum for tropical planktonic foraminifera. Palaeogeography, Palaeoclimatology, Palaeoecology, 141, 139-161.

,,,--- Premoli Silva, I. \& Thomas, E. 1996. Rapid diversification of planktonic foraminifera in the tropical Pacific (ODP Site 865) during the late Paleocene thermal maximum. Geology, 24, 423-426.

Kennett, J.P. \& StotT, L.D. 1991. Abrupt deep-sea warming, palaeoceanographic changes and benthic extinctions at the end of the Palaeocene. Nature, 353, 225-229.

Koch, P.L., ZAChos, J.C. \& Gingerich, P.D. 1992. Correlation between isotope records in marine and continental carbon reservoirs near the Palaeocene/ Eocene boundary. Nature, 358, 319-322.

LeRoy, L.W. 1953. Biostratigraphy of the Maqfi section, Egypt. Geological Society of America, Memoirs, 54.

Lu, G. \& Keller, G. 1995. Planktic foraminiferal faunal turnovers in the subtropical Pacific during the late Paleocene to early Eocene. Journal of Foraminiferal Research, 25, 97-116.

,-- - Adatte, T., Ortiz, N. \& Molina, E. 1996. Long-term $(10)^{5}$ or short-term $(10)^{3} \delta^{13} \mathrm{C}$ excursion near the Palaeocene-Eocene transition: evidence from the Tethys. Terra Nova, 8, 346-355.

Luger, P. 1985. Stratigraphie der marinen Oberkreide und des Alttertiärs im südwestlichen Obernil-Becken (SW-Ägypten) unter besonderer. Berücksichtigung der Mikropaläontologie, Palökologie und Paläogeographie. Berliner Geowissenschaftliche Abhandlungen, Reihe A: Geologie und Paläontologie, 63.

Miller, K.G., JaneceK, T.R., Katz, M.E. \& KeIl, D.J. 1987. Abyssal circulation and benthic foraminiferal changes near the Paleocene/Eocene boundary. In: Berger, W.H. \& MAyer, L.A. (eds) Special Section on Cenozoic Paleoceanography. Paleoceanography, 2, 741-761.

Molina, E., Canudo, J.I., Martinez, R.F. \& Ortiz, N. 1994. Integrated stratigraphy across the Paleocene/Eocene boundary at Caravaca, southern Spain. Eclogae Geologicae Helvetiae, 87, 47-61.

MoneChi, S. \& ANGori, E. 1998. Calcareous nannofossil events and turnover around the Paleocene/Eocene transition in some sections of Spain and Italy. In: Rey, J. \& Ronchini, F. (eds) La Limite Paléocène-Éocène en 
Europe: Evénements et Corrélations. Strata, Actes du Laboratoire de Géologie Sédimentaire et Paléontologie de l'Université Paul Sabatier, Toulouse, Série 1, 9, 97-100.

Moustafa, A.R. \& KhaliL, M.H. 1990. Structural characteristics and tectonic evolution of North Sinai fold belts. In: SAID, R. (ed.) The Geology of Egypt. Balkema, Rotterdam, 381-389.

Muzylöv, N.G., Shcherbinina, E.A., Benjamovsky, V.N., Bogolubova, L.I. \& ZAPOROZHETZ, N.I. 1995. Preliminary data of the sources of organic matter of the upper Thanetian sapropel layer of the eastern Peritethys. In: IGCP Project 308 Paleocene/Eocene Boundary Events, Meeting and Field Conference, Beer Sheva, Israel, January 8-15, 1995, Abstracts and Field Guide Volume.

ORTIZ, N. 1995. Differential patterns of benthic foraminiferal extinctions near the Paleocene/ Eocene boundary in the North Atlantic and the western Tethys. In: Langer, M.R., Lipps, J.H., Ingle, J.C. \& Sliter, W.V. (eds) Forams '94. Marine Micropaleontology, 26, 341-359.

Orue-Etxebarria, X., Apellaniz, E., Baceta, J.I., Coccioni, R., Di Leo, R., Dinares-Turell, J., Galeotti, S., Monechi, S., Núnez-Betelu, K., Pares, J.M., Payros, A., Pujalte, V., Samso, J.M., Serra-Kiel, J., Schmitz, B. \& Tosquella, J. 1996. Physical and biostratigraphic analysis of two prospective Paleocene-Eocene boundary stratotypes in the intermediate-deep water Basque Basin, western Pyrenees; the Trabakua Pass and Ermua sections. Neues Jahrbuch fuer Geologie und Palaeontologie. Abhandlungen, 201, 179-242.

PaK, D.K. \& Miller, K.G. 1992. Paleocene to Eocene benthic foraminiferal isotopes and assemblages; implications for deepwater circulation. Paleoceanography, 7, 405-422.

Pardo, A. \& Keller, G. 1996. Low latitude planktic foraminiferal incursion at the P/E boundary in the eastern boreal Paratethys (Kaurtakapy section, Kazakstan). Early Paleogene Stage Boundaries. In: International Meeting and Field Conference in Zaragoza (Spain). June 24-29, 1996. Abstracts and Field Trip Guides, 37.

, Molina, E. \& Canudo, J.I. 1997. Planktic foraminiferal turnover across the Paleocene-Eocene transition at DSDP Site 401, Bay of Biscay, North Atlantic. Marine Micropaleontology, 29, 129-158.

Robert, C. \& KennetT, J.P. 1994. Antarctic subtropical humid episode at the Paleocene-Eocene boundary; clay-mineral evidence. Geology, 22, 211-214.

SAID, R. 1990a. Cenozoic. In: SAID, R. (ed.) The Geology of Egypt. Balkema, Rotterdam, 451-486.

1990b. Red Sea coastal plain. In: SAID, R. (ed.) The Geology of Egypt. Balkema, Rotterdam, 345-359.

Schmitz, B., Asaro, F., Molina, E., Monechi, S., Von Salis, K. \& Speijer, R.P. 1997a. High-resolution iridium, $\delta^{13} \mathrm{C}, \delta^{18} \mathrm{O}$, foraminifera and nannofossil profiles across the latest Paleocene benthic extinction event at Zumaya, Spain. Palaeogeography, Palaeoclimatology, Palaeoecology, 133, 49-68.

- Charisi, S.D., Thompson, E.I. \& Speijer, R.P. 1997b. Barium, $\mathrm{SiO}_{2}$ (excess), and $\mathrm{P}_{2} \mathrm{O}_{5}$ as proxies of biological productivity in the Middle East during the Palaeocene and the latest Palaeocene benthic extinction event. Terra Nova, 9, 95-99.
- SPeiJer, R.P. \& Aubry, M.-P. 1996. Latest Paleocene benthic extinction event on the southern Tethyan shelf (Egypt); foraminiferal stable isotopic $\left(\delta^{13} \mathrm{C}, \delta^{18} \mathrm{O}\right)$ records. Geology, 24, 347-350.

Shackleton, N.J., Hall, M.A. \& Bleil, U. 1985. Carbon isotope stratigraphy, Site 577. In: Heath, G.R. \& BurcKle, L.H. (eds) Initial Reports of the Deep Sea Drilling Project, 86. US Government Printing Office, Washington, DC, 503-511.

SPEIJER, R.P. 1994. The late Paleocene benthic foraminiferal extinction as observed in the Middle East. In: LAGA, P. (ed.) Paleocene-Eocene Boundary Events. Bulletin de la Société Belge de Géologie, 103, 267-280.

\& SAmir, A.M. 1997. Globanomalina luxorensis, a Tethyan biostratigraphic marker of latest Paleocene global events. Micropaleontology, 43, 49-60.

\& VAN DER ZwaAn, G.J. 1994. The differential effect of the Paleocene/ Eocene boundary event: Extinction and survivorship in shallow to deep water Egyptian benthic foraminiferal assemblages. In: SPEIJER, R.P. Extinction and Recovery Patterns in Benthic Foraminiferal Paleocommunities across the Cretaceous/Paleogene and Paleocene/Eocene Boundaries (PhD thesis). Geologica Ultraiectina, 124, 121-168.

— Schmitz, B., Aubry, M.-P. \& Charisi, S.D. 1995. The latest Paleocene benthic extinction event: Punctuated turnover in outer neritic foraminiferal faunas from Gebel Aweina, Egypt. In: Aubry, M.-P. \& Benjamini, C. (eds) Paleocene-Eocene boundary events in space and time. Israel Journal of Earth Sciences, 44, 207-222.

— — \& VAN DER ZWAAN, G.J. 1997. Benthic foraminiferal extinction and repopulation in response to latest Paleocene Tethyan anoxia. Geology, 25, 683-686.

—, Van der Zwann, G.J. \& Schmitz, B. 1996. The impact of Paleocene/ Eocene boundary events on middle neritic benthic foraminiferal assemblages from Egypt. Marine Micropaleontology, 28, 99-132.

Stott, L.D., Sinha, A., Thiry, M., Aubry, M.-P. \& Berggren, W.A. 1996. Global $\delta^{13} \mathrm{C}$ changes across the Paleocene-Eocene boundary; criteria for terrestrial-marine correlations. In: KNox, R.W.O.B., CorfIELD, R.M. \& Dunay, R.E. (eds) Correlation of the early Paleogene in Northwest Europe. Geological Society, London, Special Publications, 101, 381-399.

Thomas, E. 1998. Biogeography of the late Paleocene benthic foraminiferal extinction. In: Aubry, M.-P., Lucas, E. \& Berggren, W.A. (eds) Late Paleocene-Early Eocene Biotic and Climatic Evolution in the Marine and Terrestrial Records. Columbia University Press, New York, 214-243.

— \& Shackleton, N.J. 1996. The Paleocene-Eocene benthic foraminiferal extinction and stable isotope anomalies. In: KNOX, R.W.O.B., CorfIELD, R.M. \& Dunay, R.E. (eds) Correlation of the early Paleogene in Northwest Europe. Geological Society, London, Special Publications, 101, 401-441.

Tualsma, R.C. \& Lohmann, G.P. 1983. Paleocene-Eocene bathyal and abyssal benthic foraminifera from the Atlantic Ocean. Micropaleontology, Special Publication, 4

Zachos, J.C., Lohmann, K.C., Walker, J.C.G. \& Wise, S.W. 1993. Abrupt climate changes and transient climates during the Paleogene; a marine perspective. Journal of Geology, 101, 191-213. 